\title{
Psychiatric treatment considerations with direct acting antivirals in hepatitis $C$
}

\author{
Sanjeev Sockalingam ${ }^{1,2^{*}}$, Alice Tseng ${ }^{3,4}$, Pierre Giguere ${ }^{5,6}$ and David Wong ${ }^{7,8}$
}

\begin{abstract}
Background: Despite recent advances in hepatitis $\mathrm{C}(\mathrm{HCV})$ treatment, specifically the addition of direct acting antivirals (DAAs), pegylated interferon-alpha remains the backbone of HCV therapy. Therefore, the impact of DAAs on the management of co-morbid psychiatric illness and neuropsychiatric sequalae remains an ongoing concern during HCV therapy. This paper provides a review of the neuropsychiatric adverse effects of DAAs and drug-drug interactions (DDIs) between DAAs and psychiatric medications.

Methods: We conducted a Pubmed search using relevant search terms and hand searched reference lists of related review articles. In addition, we searched abstracts for major hepatology conferences and contacted respective pharmaceutical companies for additional studies.
\end{abstract}

Results: Limited data is available on the neuropsychiatric adverse effects of DAAs; however, data from major clinical trials suggest that DAAs have minimal neuropsychiatric risk. DAAs can potentially interact with a variety of psychotropic agents via cytochrome P450 and p-glycoprotein interactions. Triazolam, oral midazolam, St. John's Wort, carbamazepine and pimozide, are contraindicated with DAAs. DDIs between DAAs and antidepressants, anxiolytics, hypnotics, mood stabilizers, antipsychotics and treatments for opioid dependence are summarized.

Conclusions: Although DAAs do not add significant neuropsychiatric risk, the potential for DDls is high.

Consideration of DDIs is paramount to improving medication adherence and mitigating adverse effects during HCV therapy.

Keywords: Hepatitis C, Mental disorders, Psychotropic drugs, Boceprevir, Telaprevir

\section{Background}

Treatment of hepatitis $\mathrm{C}$ virus $(\mathrm{HCV})$, a virus infecting over 170 million worldwide [1], has evolved over the last two decades and moved from interferon-alpha monotherapy to pegylated interferon-alpha (IFN $\alpha$ ) in combination with ribavirin therapy. HCV therapy with IFN $\alpha$ and ribavirin has yielded overall sustained virological response (SVR) rates of approximately $54 \%$ to $56 \%$ with SVR rates for genotype 1 approximating $45 \%$ to $50 \%$ $[2,3]$. The next generation of $\mathrm{HCV}$ therapeutic agents is direct acting antivirals (DAAs) that still require the use of interferon-ribavirin combination therapy. Protease inhibitors, specifically telaprevir or boceprevir, in combination with IFN $\alpha$ and ribavirin (i.e. triple therapy) have

\footnotetext{
* Correspondence: sanjeev.sockalingam@uhn.ca

'University Health Network, Program in Medical Psychiatry, Toronto General Hospital, 200 Elizabeth Street 8EN-228, Toronto, ON M5G 2C4, Canada ${ }^{2}$ Department of Psychiatry, University of Toronto, Toronto, ON, Canada Full list of author information is available at the end of the article
}

improved SVR rates to $70 \%$ to $75 \%$ in $\mathrm{HCV}$ genotype 1 patients $[4,5]$.

Despite these enhanced SVR rates, psychiatric illness remains a barrier to widespread $\mathrm{HCV}$ treatment uptake due to the neuropsychiatric risks associated with IFNa. It is estimated that up to $50 \%$ of patients with untreated chronic HCV suffer from psychiatric illness when substance abuse and dependence is excluded [6,7]. Lifetime rates of mood, anxiety and personality disorders in untreated HCV-infected patients have each ranged from approximately $20 \%$ to $40 \%$ [6,7]. Treatment with pegylated interferon-alpha (IFN $\alpha$ ) therapy can induce a myriad of neuropsychiatric side effects including depression in approximately $25 \%$ to $30 \%$ of patients undergoing IFNa therapy for HCV [8-11]. In addition, HCV-infected patients with pre-existing psychiatric disorders may experience an exacerbation of psychopathology secondary to IFN $\alpha$.

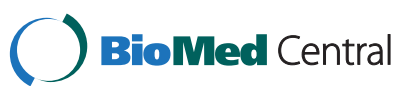


Poorly managed psychiatric illness can lead to treatment discontinuation, poor adherence to treatment and serious psychiatric sequalae, such as suicide $[12,13]$. The onset of suicidal ideation and suicide on HCV therapy coincides with the onset of IFN $\alpha$-induced depression (IFN $\alpha$-D) and requires prompt recognition and treatment to prevent these serious psychiatric sequelae [12,14]. Integrated Hepatology-Psychiatric care models have demonstrated the capacity to mitigate neuropsychiatric risks associated with $\mathrm{HCV}$ therapy through improved access to psychiatric and psychological interventions $[15,16]$.

In the era of DAAs, adherence is paramount to treatment success given the strict dosing regimen of first generation HCV protease inhibitors (PIs). First generation DAAs have high pill burdens and frequent dosing intervals. Active depression has been associated with poor antiviral therapy (ART) in patients infected with human immunodeficiency virus (HIV) [17]. Therefore, it is possible that poorly controlled psychiatric illness may compromise adherence to PI dosing schedules and as a result, reduce HCV treatment efficacy. Similar to the advent of HIV ART, first generation DAAs have also presented concerns regarding drug-drug interactions (DDIs) with medications including several psychotropic medications. Given the high prevalence of psychiatric illness in HCV-infected patients and need for psychotropic treatments for IFN $\alpha$-induced neuropsychiatric side effects, an understanding of salient DDIs involving psychotropic medications is essential to the clinical care of patients treated for HCV.

With respect to DDIs, both boceprevir and telaprevir are substrates and inhibitors of CYP3A4 [18,19]. Both agents also inhibit p-glycoprotein $[18,19]$ and telaprevir may inhibit renal transporters [20]. Approximately 50\% to $60 \%$ of available prescription medications are metabolized via CYP3A4 pathway [21,22]. Moreover, preliminary HCV data suggests that in clinical practice, $72 \%$ of patients had at least one DDI and 50\% had at least two DDIs related to DAAs [23]. Therefore, there is a high potential for DDIs with $\mathrm{HCV}$ protease inhibitors, particularly if treatment for other comorbid conditions is necessary.

Interactions may be pharmacokinetic or pharmacodynamic in nature. Pharmacodynamic interactions impact drug efficacy or toxicity in an additive, synergistic or antagonistic manner. For instance, pegylated interferon and ribavirin have CNS effects that overlap with those of the antiretroviral regimens involving efavirenz; coadministration may theoretically contribute to adverse effects including depression, mood changes, and suicidality. Clinicians may therefore wish to avoid this combination if possible, particularly in patients with a history of significant mental illness.

Pharmacokinetic interactions may result in altered concentrations of one or more interacting drugs. Negative two-way interactions have been observed between both boceprevir and telaprevir and ritonavir-boosted HIV protease inhibitors, with significant reductions in exposures of $\mathrm{HCV}$ agents and HIV protease inhibitors; therefore, telaprevir should not be coadministered with ritonavirboosted darunavir, fosamprenavir, or lopinavir [18] and boceprevir is not recommended for use with any boosted protease inhibitor [24].

Negative consequences of drug interactions may include viral breakthrough and development of resistance, sub-optimal disease/symptom management, or drug toxicity and possible non-adherence [25]. These interactions highlight the challenges of managing multiple comorbidities in patients with $\mathrm{HCV}$ infection.

The purpose of this review was to evaluate the current evidence on: (i) the neuropsychiatric adverse effects of DAAs, and (ii) the DDIs between DAAs and psychotropic agents when used in HCV patients.

\section{Methods}

We performed a Pubmed search using MeSH headings "hepatitis C" AND "boceprevir" OR "telaprevir" combined with "mental disorders", "psychotropic drugs" and "drug interactions". We limited our search to English language studies published between 2000-April 2013. References for all review articles were searched for additional studies as well as conference abstracts. Additional information on psychiatric adverse effects and DDIs with DAAs were requested from Vertex and Merck. Due to the limited literature, data on psychiatric adverse effects was also obtained from registration trials for boceprevir and telaprevir. Theoretical drug interactions were included in the respective sections. Due to available data on antidepressant efficacy in depressed HCV populations, we discussed potential DAA and antidepressant DDIs in the context of clinical evidence for specific antidepressant agents for treating depression during $\mathrm{HCV}$ therapy. Level of evidence was derived from 2 recent guidelines and existing reviews [26-29] and a previously published grading system [30] was used classify evidence for only studies examining antidepressant treatment of depression during $\mathrm{HCV}$ therapy.

\section{Results}

\section{Neuropsychiatric side effects of DAAs}

Data on neuropsychiatric adverse effects of DAAs is limited and predominantly derived from landmark clinical trials for boceprevir and telaprevir (see Table 1) [4,5,31-34]. Across trials, there was no significant difference in neuropsychiatric side effects between DAAs and treatment with peg- IFN $\alpha$ and ribavirin alone. It should be noted that the rates of neuropsychiatric sequalae from DAAs may be an underestimate, as patients with significant psychiatric illness were excluded from these 
Table 1 Psychiatric adverse effects in DAAs

\begin{tabular}{|c|c|c|c|c|c|c|}
\hline & \multicolumn{3}{|c|}{ Telaprevir trials } & \multicolumn{3}{|c|}{ Boceprevir trials } \\
\hline & ADVANCE [4] & ILLUMINATE* [31] & REALIZE [32] & SPRINT-1 [33] & SPRINT-2 [5] & RESPOND-2 [34] \\
\hline \multicolumn{7}{|c|}{ Psychiatric side effect } \\
\hline Fatigue & $57 \%(57 \%)$ & $68 \%$ & $55 \%(40 \%)$ & $68 \%(55 \%)$ & $53 \%(60 \%)$ & $54 \%(50 \%)$ \\
\hline Insomnia & $32 \%(31 \%)$ & $31 \%$ & $26 \%(26 \%)$ & $28 \%(38 \%)$ & $33 \%(32 \%)$ & $30 \%(20 \%)$ \\
\hline Irritability & $22 \%(18 \%)$ & - & $14 \%(16 \%)$ & - & $22 \%(24 \%)$ & 19\% (13\%) \\
\hline Depression & $18 \%(22 \%)$ & - & $9 \%(14 \%)$ & - & $23 \%(22 \%)$ & $12 \%(15 \%)$ \\
\hline Anxiety & $10 \%(12 \%)$ & - & - & - & - & - \\
\hline
\end{tabular}

$\%$ - percent for study arm corresponding to current standard of care for DAA.

(\%) - percent for pegylated IFNa and Ribavirin treatment arm.

*ILLUMINATE - did not have pegylated IFNa and Ribavirin treatment arm.

studies and detection of psychiatric side effects did not utilize formal psycho-diagnostic tools. Only one study published data on anxiety during triple therapy and found a comparable reported rate of anxiety in patients treated with triple therapy (10\%) versus standard therapy alone (12\%) [4]. Although studies focusing specifically on psychiatric complications of DAAs are lacking, this preliminary data suggests that DAAs confer a minimal risk of additional neuropsychiatric side effects.

\section{Antidepressant use with DAAs}

Antidepressants are used primarily in the treatment of depression and anxiety in both untreated HCV patients and patients undergoing IFN $\alpha$ therapy for HCV. Studies have explored the use of antidepressants in HCV as both prophylactic (i.e. antidepressant pre-treatment) and symptomatic treatment for IFN $\alpha-\mathrm{D}$. Two recent guidelines have specifically identified management of IFN $\alpha-D$ and provided recommendations for antidepressant therapy in HCV-infected patients (see Table 2). Based upon these guidelines and previous reviews [26], only escitalopram currently has Level 1 evidence for treating or preventing depression emerging during $\mathrm{HCV}$ treatment $[35,36]$.

Anxiety secondary to IFN $\alpha$ can also be treated with antidepressants, which are a first line treatment based upon the limited available literature (Level 4) [41,42]. Escitalopram and citalopram may be beneficial options in treating anxiety disorders in $\mathrm{HCV}$ based upon the anecdotal reports of safety in HCV [43-45] and extrapolation of evidence from non-HCV anxiety treatment guidelines [46]. Clinicians should be aware of the potential risk of dose-related QT prolongation with citalopram and escitalopram [47]. The maximum recommended dose is citalopram $20 \mathrm{mg}$ per day in patients with hepatic impairment, those 65 years of age or older, patients who are CYP2C19 poor metabolizers, or patients who are taking concomitant cimetidine or another CYP2C19 inhibitor [48]. In some countries, such as Canada, the maximum recommended dose for escitalopram in patients with hepatic impairment is $10 \mathrm{mg}$ per day due to QT prolongation concerns [49].

Drug interactions between DAAs and some antidepressants, specifically those affected by CYP 450 interactions of PIs, may lead to clinically significant adverse effects which impact tolerability to therapy for HCV. For example, SSRIs and Selective Noradrenergic Reuptake Inhibitors (SNRIs) can be associated with nausea, gastrointestinal upset, sweating and sexual dysfunction, which could emerge with PI related drug interactions.

Specific drug interactions with antidepressants and DAAs are summarized in Table 2. In a single study involving telaprevir, escitalopram area under the curve (AUC) was reduced by $35 \%$, suggesting the need for clinicians to monitor the need for dose optimization on triple therapy [50]. No significant DDI has been observed between escitalopram and boceprevir [37]. Specific antidepressants, for example trazodone, that have a high sedative potential and potential for DDIs with DAAs can lead to increased sedation and may impact overall tolerability and compliance to both agents. Therefore, the selection of antidepressant agents during HCV therapy should include consideration of potential DDIs, in order to avoid possible adverse effects, which may negatively affect $\mathrm{HCV}$ antiviral treatment adherence. Clinicians should also be aware that St. John's Wort is a potent inducer of CYP3A4 and P-gp [40], and is contraindicated with DAAs due to the potential risk for significant reductions in boceprevir or telaprevir concentrations $[18,19]$.

\section{Benzodiazepine and hypnotic use with DAAs}

Benzodiazepines may be a treatment option for anxiety symptoms in the context of $\mathrm{HCV}$ or secondary to IFNa; however, no large trials have examined the efficacy of anxiolytics in HCV $[16,41,42,51,52]$. Anecdotally, benzodiazepines have also been used short-term for insomnia in $\mathrm{HCV}$-infected patients [41]. Furthermore, the prevalence of substance dependence in $\mathrm{HCV}$ patients has cautioned the use of benzodiazepines in this patient 
Table 2 Evidence for antidepressant treatment of depression during HCV Therapy and drug interactions with DAAs

\begin{tabular}{|c|c|c|c|}
\hline $\begin{array}{l}\text { Level of } \\
\text { evidence for } \\
\text { depression } \\
\text { treatment }\end{array}$ & $\begin{array}{l}\text { Antidepressant } \\
\text { (route of metabolism) }\end{array}$ & $\begin{array}{l}\text { Known or potential } \\
\text { interactions with DAAs }\end{array}$ & Comments \\
\hline Level 1 & Escitalopram (CYP2C19, 3A4 >> 2D6) & $\begin{array}{l}\text { No interaction observed with } \\
\text { boceprevir [37] 35\% } \downarrow \\
\text { escitalopram AUC with telaprevir } \\
\text { [38] }\end{array}$ & $\begin{array}{l}\text { Boceprevir: no dose adjustment required. } \\
\text { Telaprevir: May need to titrate escitalopram } \\
\text { dose according to clinical response. }\end{array}$ \\
\hline \multirow[t]{2}{*}{ Level 2} & Citalopram (CYP2C19, 3A4 >> 2D6) & $\begin{array}{l}\text { Potential for } \downarrow \text { antidepressant } \\
\text { concentrations based on } \\
\text { escitalopram interaction data. }\end{array}$ & $\begin{array}{l}\text { Monitor and titrate dose according to clinical } \\
\text { response. }\end{array}$ \\
\hline & Paroxetine* (CYP2D6) & $\begin{array}{l}\text { No interaction expected based on } \\
\text { known pharmacologic } \\
\text { characteristics. }\end{array}$ & $\begin{array}{l}\text { Monitor and titrate dose according to clinical } \\
\text { response. }\end{array}$ \\
\hline \multirow[t]{5}{*}{ Level 4} & Bupropion (CYP2B6), Fluoxetine (CYP2D6) & $\begin{array}{l}\text { No interaction expected based on } \\
\text { known pharmacologic } \\
\text { characteristics. }\end{array}$ & $\begin{array}{l}\text { Monitor and titrate dose according to clinical } \\
\text { response. }\end{array}$ \\
\hline & $\begin{array}{l}\text { Sertraline (CYP2B6 > 2C9/19, 3A4, 2D6, UGT1A1 } \\
\text { - possible), Mirtazapine (CYP2D6, 1A2, 3A4), } \\
\text { Venlafaxine (CYP2D6 > CYP3A4) }\end{array}$ & $\begin{array}{l}\text { Potential for } \uparrow \text { sertraline, } \\
\text { mirtazapine, venlafaxine } \\
\text { concentrations (clinical } \\
\text { significance unknown). }\end{array}$ & $\begin{array}{l}\text { Use with caution; monitor and titrate dose } \\
\text { according to clinical response. }\end{array}$ \\
\hline & Desvenlafaxine (UGT>>3A4) [39,40] & $\begin{array}{l}\text { Potential for } \uparrow \text { desvenlafaxine } \\
\text { concentrations (clinical } \\
\text { significance unknown). }\end{array}$ & $\begin{array}{l}\text { Monitor and titrate antidepressant dose } \\
\text { according to clinical response. }\end{array}$ \\
\hline & $\begin{array}{l}\text { Tricyclic antidepressants i.e. Desipramine } \\
\text { (CYP2D6>>UGT), Imipramine (CYP2D6, 1A2, } \\
\text { 2C19, 3A > UGT), Trazodone** (CYP2D6> } \\
\text { CYP3A) }\end{array}$ & $\begin{array}{l}\text { Potential increase in TCA } \\
\text { concentrations resulting in } \\
\text { dizziness, hypotension and } \\
\text { syncope. }\end{array}$ & $\begin{array}{l}\text { Use with caution with DAAs, lower TCA } \\
\text { doses are recommended. }\end{array}$ \\
\hline & Nortriptyline (CYP2D6) & $\begin{array}{l}\text { No interaction expected based on } \\
\text { known pharmacologic } \\
\text { characteristics. }\end{array}$ & $\begin{array}{l}\text { Monitor and titrate dose according to clinical } \\
\text { response. }\end{array}$ \\
\hline \multirow{3}{*}{$\begin{array}{l}\text { Avoid } \\
\text { (exceptional } \\
\text { circumstances } \\
\text { only) }\end{array}$} & Duloxetine (CYP1A2, 2D6) & Duloxetine: risk of hepatotoxicity. & Duloxetine is contraindicated in liver disease. \\
\hline & Nefazodone (CYP3A4) & $\begin{array}{l}\text { Nefazodone: potential for } \uparrow \\
\text { nefazodone and/or DAA } \\
\text { concentrations; also risk of } \\
\text { hepatotoxicity. }\end{array}$ & $\begin{array}{l}\text { Nefazone was discontinued in the United } \\
\text { States and Canada in } 2003 \text { due to } \\
\text { hepatotoxicity concerns. Avoid use in liver } \\
\text { disease. }\end{array}$ \\
\hline & $\begin{array}{l}\text { St. John's Wort (hypericum perforatum); } \\
\text { induces CYP3A4 and P-gp [40]. }\end{array}$ & $\begin{array}{l}\text { Potential for } \downarrow \text { DAA } \\
\text { concentrations. }\end{array}$ & $\begin{array}{l}\text { St. John's Wort is contraindicated with } \\
\text { boceprevir [19] and telaprevir [18]. }\end{array}$ \\
\hline
\end{tabular}

*Evidence in RCT for depressed mood component of major depression only.

**Trazodone is primarily used clinically for treating insomnia.

Level of Evidence: Level I ( 22 RCTs or meta-analysis), Level 2 (1 RCT), Level 4 (Case reports/series or expert opinion).

population. In general, short-acting benzodiazepines should be avoided due to potential rebound effect on anxiety and long-term benzodiazepine use may lead to tolerance and dependence.

If benzodiazepines are used, lorazepam, oxazepam or temazepam are preferred due to the reliance on glucuronidation, a process that is relatively preserved in patients with significant liver disease [53]. Furthermore, these three agents are the least susceptible to pharmacokinetic interactions with DAAs since they are not metabolized through the cytochrome P450 system. Most other benzodiazepine agents undergo metabolism solely or partially through CYP3A4, and thus concentrations may be increased by DAAs via CYP3A4 inhibition. Triazolam and oral midazolam are contraindicated with boceprevir and telaprevir, due to hypothesized or documented significant interactions. When administered orally, midazolam exposures were increased $430 \%$ in the presence of boceprevir [54] and almost 9-fold in the presence of telaprevir [55]. Intravenous midazolam concentrations increased 3.4-fold when co-administered with telaprevir [55]. Thus, while intravenous midazolam is not absolutely contraindicated with PIs, it is recommended that this combination be administered with caution in a setting which allows for close clinical monitoring for prolonged sedation and/or respiratory depression, and that dose adjustment of intravenous midazolam should be considered [19].

Zolpidem is metabolized through a variety of CYP450 isozymes, including CYP3A, 2C9, 1A2, 2D6, and 2C19. In the presence of steady-state telaprevir, zolpidem exposures were unexpectedly reduced by $47 \%$ [56]. Close 
monitoring and dose titration of zolpidem is recommended if this agent is coadministered with telaprevir. Zopiclone is also metabolized predominantly by CYP3A4 and to a lesser degree by CYP2C8 and CYP2C9. Zopiclone concentrations may theoretically be increased by DAAs and require close monitoring. Most other benzodiazepines should be used cautiously in patients on DAAs. Clinicians may consider starting with a decreased benzodiazepine dose and monitoring for benzodiazepine-related toxicity, or selecting an alternate agent such as lorazepam, oxazepam or temazepam. Dose reductions are also recommended in patients with severe liver impairment as per product monographs $[18,19]$.

\section{Anticonvulsant use with DAAs}

Anticonvulsants can be used as mood stabilizers for new onset or de-stabilized bipolar disorder during IFN $\alpha$ therapy for HCV. Studies on the efficacy of anticonvulsants as moodstabilizers in $\mathrm{HCV}$ are limited to case reports and as a result, treatment often follows non-HCV bipolar treatment guidelines [30].

Lithium is a preferred moodstabilizer due its renal excretion and minimal dose adjustment in patients with $\mathrm{HCV}$ except in patients with shifting fluid balance resulting from decompensated cirrhosis [57]. Lithium has no known drug interactions with DAAs. Valproic acid has no significant DDIs with DAAs; however, valproic acid use in $\mathrm{HCV}$ has been limited by its purported risk of hepatotoxicity [58]. Nonetheless, in a study of patients with less severe $\mathrm{HCV}$ disease, elevations in alanine aminotransferase (ALT) were comparable between valproic acid and other psychotropic agents [59].

Amongst the remaining moodstabilizers, carbamazepine is contraindicated due to induction of cytochrome P450 3A4 and potential for decreasing boceprevir or telaprevir levels (see Table 3). Lamotrigine undergoes extensive metabolism by UDP-glucuronosyltransferase (UGT) 1A4 [60]. This metabolic pathway is not inhibited or induced by boceprevir or telaprevir. Lamotrigine has been associated with severe rash, including Steven's Johnson rash. Given that DAAs, particularly telaprevir, have also been associated with severe rashes, it is recommended to use extra precautions if coadministration is required. Gabapentin and pregabalin are not effective moodstabilizers for bipolar disorder in monotherapy [61]; however, based upon data from non-HCV populations pregabalin and gabapentin can be efficacious in treating co-morbid generalized anxiety disorder (GAD) in $\mathrm{HCV}$. Both pregabalin and gabapentin have no significant drug interactions with $\mathrm{HCV}$ triple therapy

Table 3 Anticonvulsant drug interactions with DAAs

\begin{tabular}{|c|c|c|}
\hline Drug (route of metabolism) & $\begin{array}{l}\text { Known or potential interactions with } \\
\text { DAAs }\end{array}$ & Comments \\
\hline Lithium (renal) & $\begin{array}{l}\text { No interaction expected based on known } \\
\text { pharmacologic characteristics }\end{array}$ & $\begin{array}{l}\text { Monitor and titrate dose } \\
\text { according to clinical response } \\
\text { and serum levels. }\end{array}$ \\
\hline $\begin{array}{l}\text { Valproic Acid, divalproex } \\
\text { Parent: UGT (50\%), minor CYP dependent } \\
\text { oxidation pathway }(<10 \%) \\
\text { Inhibitor of UGT,CYP2C } 9 / 19\end{array}$ & $\begin{array}{l}\text { No interaction expected based on known } \\
\text { pharmacologic characteristics }\end{array}$ & $\begin{array}{l}\text { Monitor and titrate dose according } \\
\text { to clinical response and serum levels. }\end{array}$ \\
\hline $\begin{array}{l}\text { Carbamazepine } \\
\text { Parent: CYP3A>> 2C8, 1A2 } \\
\text { Inducer of CYP3A, 2C9, 2C19, UGT and possibly } 1 \text { A2 }\end{array}$ & Potential for $\downarrow$ DAAs concentrations & $\begin{array}{l}\text { Carbamazepine is contraindicated } \\
\text { with boceprevir [19] Co-administration } \\
\text { of telaprevir with potent CYP3A4 inducers } \\
\text { such as carbamazepine may lead to } \\
\text { reduced DAA plasma concentrations } \\
\text { and decreased efficacy [18] Carbamazepine } \\
\text { clearance can also potentially be decreased } \\
\text { [62]. Consider an alternate agent with non- } \\
\text { inducing metabolic properties. }\end{array}$ \\
\hline $\begin{array}{l}\text { Oxcarbazepine } \\
\text { Parent: UGT Inhibitor of CYPC19; Potent inducer of CYP3A4. } \\
\text { Relative to carbamazepine, oxcarbazepine } \\
\text { inducing effect is } 54 \% \text { lower [63] }\end{array}$ & Potential for $\downarrow$ DAAs concentrations & $\begin{array}{l}\text { Co-administration of boceprevir and } \\
\text { telaprevir with potent CYP3A4 inducers, } \\
\text { may lead to reduced DAA plasma } \\
\text { concentrations and decreased efficacy. } \\
\text { Consider an alternate agent with non- } \\
\text { inducing metabolic properties [64]. }\end{array}$ \\
\hline Lamotrigine (UGT) & $\begin{array}{l}\text { No interaction expected based on known } \\
\text { pharmacologic characteristics }\end{array}$ & $\begin{array}{l}\text { Monitor and titrate dose according to } \\
\text { clinical response. }\end{array}$ \\
\hline Gabapentin (Renal) & $\begin{array}{l}\text { No interaction expected based on known } \\
\text { pharmacologic characteristics }\end{array}$ & $\begin{array}{l}\text { Monitor and titrate dose according } \\
\text { to clinical response. }\end{array}$ \\
\hline Pregabalin (Renal) & $\begin{array}{l}\text { No interaction expected based on known } \\
\text { pharmacologic characteristics }\end{array}$ & $\begin{array}{l}\text { Monitor and titrate dose according } \\
\text { to clinical response. }\end{array}$ \\
\hline
\end{tabular}


involving DAAs as they are both predominantly renally excreted. Table 3 provides a summary of anticonvulsant drug interactions with DAAs.

\section{Antipsychotic use with DAAs}

Antipsychotic medications can be used during $\mathrm{HCV}$ therapy to stabilize pre-existing mood or psychotic disorders in patients or to treat IFNa-induced mood or psychotic symptoms secondary. Patients with severe mental illness, such as schizophrenia $[65,66]$ and bipolar disorder [67] have been shown to have higher rates of $\mathrm{HCV}$ compared to the general population and thus, it may not be uncommon to treat patients with HCV who are already treated with antipsychotic medications for severe mental illness. Albeit rare, antipsychotic medications may be used to treat de novo secondary to IFNa
[68-72]. In addition, atypical antipsychotics can be used for mood stabilization and irritability emerging during HCV therapy $[41,73,74]$.

Several DDIs and side effects should be considered when prescribing antipsychotic medication in the context of HCV triple therapy (see Table 4). Telaprevir and boceprevir may interact with antipsychotics prone to corrected QT (QTc) interval prolongation and elevations in plasma levels could increase QTc prolongation risk. As a result, pimozide, a conventional antipsychotic with a high propensity for QTc prolongation, is contraindicated when treating patients with boceprevir and telaprevir. Amongst the atypical antipsychotics, ziprasidone, which is metabolized by CYP 3A4, is associated with an increased QTc prolongation risk amongst novel antipsychotics [75]. Initiation of ziprasidone should include a baseline

Table 4 Antipsychotic drug interactions with DAAs

\begin{tabular}{ll}
\hline Drug (route of metabolism) & Known or potential interactions wit \\
\hline Aripiprazole (CYP3A4, 2D6) & $\begin{array}{l}\text { Potential for } \uparrow \text { aripiprazole } \\
\text { concentrations }\end{array}$ \\
& \\
Asenapine (UGT1A4, CYP1A2) & $\begin{array}{l}\text { No interaction expected based on } \\
\text { known pharmacologic } \\
\text { characteristics }\end{array}$ \\
Clozapine (CYP1A2> 3A4,P-gp) & $\begin{array}{l}\text { Potential for } \uparrow \text { clozapine } \\
\text { concentrations }\end{array}$
\end{tabular}

Olanzapine (CYP1A2, UGT,PGP>2D6)

Paliperidone

Primarily renally excreted (59\%);

minor CYP dependant pathway

(CYP3A4, PGP > 2D6), but may not be

clinically significant. Substrate

and inhibitor of P-gp [79]

Quetiapine (CYP3A4>2D6, P-gp)

Risperidone (CYP2D6, P-gp>3A4)

Ziprasidone (CYP3A4>1A2)

Minor CYP dependant

pathway (33\%) [78]
No interaction expected based on known pharmacologic characteristics

Potential for $\uparrow$ paliperidone concentrations

Potential for $\uparrow$ quetiapine concentrations

Potential for $\uparrow$ risperidone concentrations

Potential for $\uparrow$ ziprasidone concentrations

\section{Comments \\ Use combination with caution, and monitor for aripiprazole-related toxicity (sedation, sinus tachycardia, nausea/vomiting, or dystonic reactions). Consider starting with a decreased aripiprazole dose or select an alternate agent.}

Monitor and titrate dose according to clinical response [76].

Clozapine has a narrow therapeutic index. Use combination with caution, and monitor for clozapine-related toxicity (Bone marrow suppression, generalized seizures, severe sedation, confusion and delirium). Consider starting with a decreased clozapine dose or select an alternate agent. When available, clozapine therapeutic drug monitoring is recommended $[77,78]$.

Monitor and titrate dose according to clinical response.

DAAs inhibit both CYP3A4 and P-gp, and clinically significant interaction, although unlikely, cannot be ruled out. Use combination with caution, and monitor for possible paliperidonerelated toxicity.

Use combination with caution, and monitor for quetiapine-related toxicity (excessive sedation). Consider starting with a decreased quetiapine dose or select an alternate agent [80].

Unlike its active metabolite paliperidone, risperidone is primarily metabolized by CYP2D6. However, the elimination of paliperidone may be impaired. Use combination with caution, and monitor for possible risperidone-related toxicity.

Although clinically significant interaction unlikely, use combination with caution, and monitor for possible ziprasidonerelated toxicity (QTc). 
electrocardiogram (ECG) and this may need to be reassessed on triple therapy for $\mathrm{HCV}$ due to DDI.

Several antipsychotics are metabolized via CYP3A4/5, which are inhibited by current DAAs. Sedating antipsychotics that are metabolized by CYP3A4, such as quetiapine, may be increased via DDIs secondary to DAAs and could result in more pronounced sedation that could hinder compliance with multiple daily dosing regimens of DAAs. Clozapine is also metabolized in part by CYP3A4 and clozapine levels should be monitored closely during $\mathrm{HCV}$ triple therapy as higher doses of clozapine have been associated with an increased adverse effects including seizures [81]. Treatment with clozapine is further complicated during HCV therapy due to additive theoretical risks of agranulocytosis and neutropenia related specifically to IFN $\alpha$ effects. Therefore, clozapine monitoring protocols may need to be adjusted due to this risk and vigilant follow-up monitoring for signs of infection is recommended [82].

Lastly, DAAs are known inhibitors of P-gp and many second generation antipsychotics are substrates of P-gp [83]. In theory, inhibition of P-gp may lead to increased exposure of the antipsychotic in the CSF, and may be associated with enhanced effectiveness or toxicity [79]. Despite the absence of documented metabolic drug interactions, caution is to be exercised with known substrates of P-gp (quetiapine, risperidone, olanzapine) and DAAs.

\section{Addictions agents with DAAs}

Given the higher rates of substance dependence in $\mathrm{HCV}$-infected patient populations compared to the general population [6], treatment of concurrent substance use disorders, either through harm reduction or abstinence based models, is an important component of preHCV therapy stabilization. To date, no studies have determined if the addition of DAAs to HCV treatment increased the risk of substance use relapse.

In some $\mathrm{HCV}$-infected populations, methadone treatment is a core component of $\mathrm{HCV}$ treatment stabilization in patients at risk of opioid and polysubstance dependence $[84,85]$. Methadone is metabolized by CYP2C19 and 3A4. The coadministration of methadone and telaprevir was shown to result in a $21 \%$ decrease of the active enantiomer R-methadone exposure [86]. However, free concentrations of R-methadone were unaffected and therefore no dosage adjustment is necessary. Buprenorphine pharmacokinetics are not affected by telaprevir and is safe for coadministration [87]. Boceprevir was studied with methadone, buprenorphine and naloxone. Similar to telaprevir, boceprevir led to a $15 \%$ decrease of R-methadone exposure. No free methadone concentrations were performed. Boceprevir was also associated with an increase of naloxone and buprenorphine exposure by 19 and 33\% respectively, which is considered to be clinically non-significant [88].

\section{Discussions}

Psychiatric disorders are highly prevalent in patients infected with chronic $\mathrm{HCV}$ and until IFN $\alpha$-free therapies for $\mathrm{HCV}$ emerge, it is evident that neuropsychiatric risks of HCV therapy continue to be a significant concern. This review provides further information on the impact of DAAs on the neuropsychiatric sequelae of HCV therapy and clarifies the potential for DDIs with psychotropic medications.

First, DAAs do not appear to confer additional neuropsychiatric risks to patients undergoing $\mathrm{HCV}$ triple therapy. However, the use of DAAs warrants careful recognition of potential DDIs with psychotropic agents and an analysis of whether psychotropic regimens should be changed due to significant DDI risks. In addition, the potential for DDIs with psychotropic agents may exacerbate side effects and may interfere with DAA compliance, thus reducing $\mathrm{HCV}$ treatment efficacy.

The potential for clinically significant and complex interactions between DAAs and psychotropic drug classes is high. Interactions are primarily pharmacokinetic in nature, and may result in increased or decreased exposures of either/both drug classes. Potential clinical consequences of such interactions may include increased toxicity or potential under dosing. In the case of DAAs, sub-therapeutic concentrations may lead to treatment failure and development of resistance. Whenever possible, non-essential medications should be discontinued for the duration of HCV treatment.

Steps to identifying and managing interactions include ensuring that medication records are up to date at each patient visit (i.e., medication reconciliation), use of a systematic approach to identify combinations of potential concern, consulting pertinent $\mathrm{HCV}$ drug interaction resources, and frequent patient monitoring. Other management options include altering dosing frequency or replacing one agent with another drug with lower interaction potential. Given the complexity of this field, clinicians are encouraged to consult with pharmacists or physicians with expertise in HCV pharmacology when managing drug therapy of co-infected patients.

The results of this review can be beneficial in informing the selection of psychotropic agents for common psychiatric presentations in HCV. Using self-report or clinician rated psychiatric scales to measure treatment response to pharmacotherapy can be beneficial in monitoring relapse following psychotropic dose adjustments due to DDIs. For example, both the Beck Depression Inventory-II [89] or Patient Health Questionnaire-9 [87] for depression have been used and validated in this patient population. Further, awareness and education of 
the entire interdisciplinary treatment team is important in order to assist with prompt recognition of psychiatric symptoms, appropriate selection of psychotropic agents with minimal drug interactions and to minimize adverse effects to increased overall treatment adherence. The importance of interdisciplinary models of $\mathrm{HCV}$ care is evident from studies showing comparable HCV treatment adherence rates and outcomes for patients with either active substance use $[84,90]$ or severe mental illness $[91,92]$ as compared to controls.

\section{Conclusions}

In summary, this review summarizes the emerging body of evidence in this area but also acknowledges the remaining gaps in the literature. Studies utilizing more detailed psychiatric assessment tools during HCV treatment with DAAs are needed to increase our understanding of DAA related psychiatric complications. Additional drug interaction studies between DAAs and commonly used psychotropic agents are urgently needed. The results of these studies will be essential to guiding clinicians presented with challenges in interpreting DDI risks related to psychiatric care in the era of HCV triple therapy, in order to optimize HCV treatment outcomes and as well as management of psychiatric symptomatology.

\section{Competing interest}

The authors have no funding interest to declare with respect to this study.

\section{Authors' contribution}

SS has served as a speaker for Roche Canada. AT has received honoraria for consulting work with Merck- Canada and Vertex Pharmaceuticals. PG has served as a speaker, a consultant and an advisory board member for Vertex Pharmaceuticals and Merck Frosst Canada. DKW has received nursing support from Roche Canada and Shering-Plough Canada. All authors read and approved the final manuscript.

\section{Author details}

'University Health Network, Program in Medical Psychiatry, Toronto General Hospital, 200 Elizabeth Street 8EN-228, Toronto, ON M5G 2C4, Canada. ${ }^{2}$ Department of Psychiatry, University of Toronto, Toronto, ON, Canada. ${ }^{3}$ University Health Network, Immunodeficiency Clinic, Toronto, ON, Canada. ${ }^{4}$ Faculty of Pharmacy, University of Toronto, Toronto, ON, Canada. ${ }^{5}$ The Ottawa Hospital, Immunodeficiency Clinic, Ottawa, ON, Canada. ${ }^{6}$ The Ottawa Hospital Research institute, Ottawa, ON, Canada. ${ }^{7}$ Toronto Western Hospital Liver Centre, Toronto, ON, Canada. ${ }^{8}$ Faculty of Medicine, University of Toronto, Toronto, ON, Canada.

Received: 26 January 2013 Accepted: 4 May 2013

Published: 14 May 2013

\section{References}

1. Wasley A, Alter MJ: Epidemiology of hepatitis C: geographic differences and temporal trends. Semin Liver Dis 2000, 20(1):1-16.

2. Fried MW, Shiffman ML, Reddy KR, Smith C, Marinos G, Goncales FL Jr, Haussinger D, Diago M, Carosi G, Dhumeaux D, et al: Peginterferon alfa-2a plus ribavirin for chronic hepatitis C virus infection. N Engl J Med 2002, 347(13):975-982.

3. Manns MP, McHutchison JG, Gordon SC, Rustgi VK, Shiffman M, Reindollar R, Goodman ZD, Koury K, Ling M, Albrecht JK: Peginterferon alfa-2b plus ribavirin compared with interferon alfa-2b plus ribavirin for initial treatment of chronic hepatitis C: a randomised trial. Lancet 2001, 358(9286):958-965.
4. Jacobson IM, McHutchison JG, Dusheiko G, Di Bisceglie AM, Reddy KR, Bzowej NH, Marcellin P, Muir AJ, Ferenci P, Flisiak R, et al: Telaprevir for previously untreated chronic hepatitis $C$ virus infection. N Engl J Med 2011, 364(25):2405-2416.

5. Poordad F, McCone J Jr, Bacon BR, Bruno S, Manns MP, Sulkowski MS, Jacobson IM, Reddy KR, Goodman ZD, Boparai N, et al: Boceprevir for untreated chronic HCV genotype 1 infection. N Engl J Med 2011, 364(13):1195-1206.

6. El-Sarag HB, Kunik M, Richardson P, Rabaneck L: Psychiatric disorders among veterans with hepatitis C infection. Gastroenterology 2002, 123:476-482.

7. Yovtcheva SP, Rifai MA, Moles JK, Linden BJV: Psychiatric comorbidity among hepatitis C-positive patients. Psychosomatics 2001, 42:411-415.

8. Horikawa N, Yamazaki T, Izumi N, Uchihara M: Incidence and clinical course of major depression in patients with chronic hepatitis type $C$ undergoing interferon-alpha therapy: a prospective study. Gen Hosp Psych 2003, 25:34-38.

9. Morasco BJ, Loftis JM, Indest DW, Ruimy S, Davison JW, Felker B, Hauser P: Prophylactic antidepressant treatment in patients with hepatitis $C$ on antiviral therapy: a double-blind, placebo-controlled trial. Psychosomatics 2010, 51(5):401-408.

10. Morasco BJ, Rifai MA, Loftis JM, Indest DW, Moles JK, Hauser P: A randomized trial of paroxetine to prevent interferon-alpha-induced depression in patients with hepatitis C. J Affect Disord 2007, 103:83-90.

11. Hauser P, Khosla J, Aurora H, Laurin J, Kling MA, Hill J, Gulati M, Thornton AJ, Schultz RL, Valentine $A D$, et al: A prospective study of the incidence and open-label treatment of interferon-induced major depressive disorder in patients with hepatitis C. Mol Psychiatry 2002, 7(9):942-947.

12. Dieperink E, Ho SB, Tetrick L, Thuras P, Dua K, Willnebring ML: Suicidal ideation during interferon-alpha $2 \mathrm{~b}$ and ribavirin treatment of patients with chronic hepatitis C. Gen Hosp Psych 2004, 26:237-240.

13. Ademmer K, Beutel M, Bretzel R, Jaeger C, Reimer C: Suicidal ideation with IFN-alpha and ribavirin in a patient with hepatitis C. Psychosomatics 2001, 42(4):365-367.

14. Sockalingam S, Links PS, Abbey SE: Suicide risk in hepatitis $C$ and during interferon-alpha therapy: a review and clinical update. J Viral Hepat 2011, 18(3):153-160.

15. Schaefer M, Hintzpeter A, Mohmand A, Janssen G, Pich M, Schwaiger M, Sarkar R, Friebe A, Heinz A, Kluschke M, et al: Hepatitis C treatment in "difficult-to-treat" psychiatric patients with pegylated interferon-alpha and ribavirin: response and psychiatric side effects. Hepatology 2007, 46:991-998.

16. Neri S, Bertino G, Petralia A, Giancarlo C, Rizzotto A, Calvagno GS, Mauceri B, Abate G, Boemi P, Di Pino A, et al: A multidisciplinary therapeutic approach for reducing the risk of psychiatric side effects in patients with chronic hepatitis $C$ treated with pegylated interferon alpha and ribavirin. J Clin Gastroenterol 2010, 44(9):e210-217.

17. Moore DJ, Blackstone K, Woods SP, Ellis RJ, Atkinson JH, Heaton RK, Grant I: Methamphetamine use and neuropsychiatric factors are associated with antiretroviral non-adherence. AIDS Care 2012, 24(12):1504-1513.

18. Vertex Pharmaceuticals Inc: Incivek (telaprevir) Product Monograph. Cambridge, MA: Vertex Pharmaceuticals Incorporated; 2012.

19. Merck Canada Inc: Victrelis (boceprevir) Product Monograph. Kirkland, QC: Merck Canada Inc; January 16, 2013.

20. Kunze A, Huwyler J, Camenisch G, Gutmann H: Interaction of the antiviral drug telaprevir with renal and hepatic drug transporters. Biochem Pharmacol 2012, 84(8):1096-1102.

21. Guengerich FP: Cytochrome P450s and other enzymes in drug metabolism and toxicity. AAPS J 2006, 8(1):E101-111.

22. Flockhart DA, Tanus-Santos JE: Implications of cytochrome P450 interactions when prescribing medication for hypertension. Arch Intern Med 2002, 162(4):405-412.

23. Kipp G, Mohammad R, Lin A, Johnson H: Evaluation of pharmacist identified and mitigated drug-drug interactions in hepatitis $C$ virus infected patients starting telaprevir or boceprevir. In The 63rd Annual Meeting of the American Association for the Study of Liver Diseases. Boston, MA; 2012

24. Hulskotte EGJ, Feng H-P, Xuan F, van Zutven M, O'Mara E, Youngberg S, Wagner JA, Butterton JR: Pharmacokinetic interaction between the HCV protease inhibitor boceprevir and ritonavir-boosted HIV-1 protease inhibitors atazanavir, lopinavir, and darunavir. Clin Infect Dis 2013, 56(5):718-726. 
25. Marzolini C, Elzi L, Gibbons S, Weber R, Fux C, Furrer H, Chave JP, Cavassini M, Bernasconi E, Calmy A, et al: Prevalence of comedications and effect of potential drug-drug interactions in the Swiss HIV Cohort Study. Antivir Ther 2010, 15(3):413-423.

26. Sockalingam S, Abbey SE: Managing depression during hepatitis $C$ treatment. Can J Psychiatry 2009, 54(9):614-625.

27. Schaefer M, Capuron L, Friebe A, Diez-Quevedo C, Robaeys G, Neri S, Foster GR, Kautz A, Forton D, Pariante CM: Hepatitis C infection, antiviral treatment and mental health: A European expert consensus statement. J Hepatol 2012, 57(6):1379-1390.

28. Ramasubbu R, Taylor VH, Saaman Z, Sockalingham S, Li M, Patten S, Rodin G, Schaffer A, Beaulieu S, McIntyre RS: The Canadian Network for Mood and Anxiety Treatments (CANMAT) task force recommendations for the management of patients with mood disorders and select comorbid medical conditions. Ann Clin Psychiatry 2012, 24(1):91-109.

29. Baraldi S, Hepgul N, Mondelli V, Pariante CM: Symptomatic treatment of interferon-alpha-induced depression in hepatitis C: a systematic review. J Clin Psychopharmacol 2012, 32(4):531-543.

30. Yatham LN, Kennedy SH, Schaffer A, Parikh SV, Beaulieu S, O'Donovan C, MacQueen G, McIntyre RS, Sharma V, Ravindran A, et al: Canadian Network for Mood and Anxiety Treatments (CANMAT) and International Society for Bipolar Disorders (ISBD) collaborative update of CANMAT guidelines for the management of patients with bipolar disorder: update 2009. Bipolar Disord 2009, 11(3):225-255.

31. Sherman KE, Flamm SL, Afdhal NH, Nelson DR, Sulkowski MS, Everson GT, Fried MW, Adler M, Reesink HW, Martin M, et al: Response-guided telaprevir combination treatment for hepatitis $C$ virus infection. $N$ Engl Med 2011, 365(11):1014-1024.

32. Zeuzem S, Andreone P, Pol S, Lawitz E, Diago M, Roberts S, Focaccia R, Younossi Z, Foster GR, Horban A, et al: Telaprevir for retreatment of HCV infection. N Engl J Med 2011, 364(25):2417-2428.

33. Kwo PY, Lawitz EJ, McCone J, Schiff ER, Vierling JM, Pound D, Davis MN, Galati JS, Gordon SC, Ravendhran N, et al: Efficacy of boceprevir, an NS3 protease inhibitor, in combination with peginterferon alfa- $2 \mathrm{~b}$ and ribavirin in treatment-naive patients with genotype 1 hepatitis $C$ infection (SPRINT-1): an open-label, randomised, multicentre phase 2 trial. Lancet 2010, 376(9742):705-716.

34. Bacon BR, Gordon SC, Lawitz E, Marcellin P, Vierling JM, Zeuzem S, Poordad F, Goodman ZD, Sings HL, Boparai N, et al: Boceprevir for previously treated chronic HCV genotype 1 infection. N Engl J Med 2011, 364(13):1207-1217.

35. Schaefer M, Sarkar R, Knop V, Effenberger S, Friebe A, Helnze L, Spengler U, Schlaepfer T, Relmer J, Bugglsch P, et al: Escitalopram for the prevention of peginterferon-alpha2a-associated depression in hepatitis $C$ virus-infected patients without previous psychiatric disease. Ann Intern Med 2012, 157:94-103.

36. Gleason OC, Fucci JC, Yates WR, Philipsen MA: Preventing relapse of major depression during interferon-alpha therapy for hepatitis C-A pilot study. Dig Dis Sci 2007, 52(10):2557-2563.

37. Hulskotte EGJ, Gupta S, Xuan F, van Zutven MGJA, O'Mara E, Galitz L, Wagner JA, Butterton JR: Coadministration of the HCV protease inhibitor boceprevir has no clinically meaningful effect on the pharmacokinetics of the selective serotonin reuptake inhibitor escitalopram in healthy volunteers. Global Antiviral Journal 2011, 7(1):108-109. abstract.

38. Van Heeswijk RPG, Boogaerts G, De Paepe E, Van Solingen-Ristea R, Garg V Beaumont M: The pharmacokinetic interaction between escitalopram and the investigational HCV protease inhibitor telaprevir [abstract 12]. Rev Antiviral Ther Infect Dis 2010, 5:12-13.

39. Nichols Al, Behrle JA, Parks V, Richards LS, McGrory SB, Posener J, Patat A, Paul J: Pharmacokinetics, pharmacodynamics, and safety of desvenlafaxine, a serotonin-norepinephrine reupatke inhibitor. J Bioequiv Availab 2013, 5:1.

40. Zhou SF, Lai X: An update on clinical drug interactions with the herbal antidepressant St. John's wort. Current drug metabolism 2008, 9(5):394-409.

41. Maddock C, Baita A, Orru MG, Sitzia R, Costa A, Muntoni E, Farci MG, Carpiniello B, Pariante CM: Psychopharmacological treatment of depression, anxiety, irritability and insomnia in patients receiving interferon-alpha: a prospective case series and a discussion of biological mechanisms. J Psychopharmacol 2004, 18(1):41-46.

42. Dieperink E, Leskela J, Dieperink ME, Evans B, Thuras P, Ho SB: The effect of pegylated interferon-alpha $2 \mathrm{~b}$ and ribavirin on posttraumatic stress disorder symptoms. Psychosomatics 2008, 49(3):225-229.
43. Gleason OC, Yates WR, Philipsen MA, Isbell MD, Pollock BG: Plasma levels of citalopram in depressed patients with hepatitis C. Psychosomatics 2004, 45(1):29-33

44. Gleason OC, Yates WR, Isbell MD, Philipsen MA: An open-label trial of citalopram for major depression in patients with hepatitis C. J Clin Psychiatry 2002, 63(3):194-198.

45. Gleason OC, Yates WR, Philipsen MA: Major depressive disorder in hepatitis C: an open-label trial of escitalopram. Prim Care Companion J Clin Psychiatry 2005, 7(5):225-230.

46. Swinson RP, Antony MM, Bleau P, Chokka P, Craven M, Fallu A, Katzman M, Kjernisted K, Lanius R, Manassis K, et al: Clinical Practice Guidelines: Management of Anxiety Disorders. Can J Psychiatry 2006, 51(8):2.

47. Castro VM, Clements CC, Murphy SN, Gainer VS, Fava M, Weilburg JB, Erb JL, Churchill SE, Kohane IS, losifescu DV, et al: QT interval and antidepressant use: a cross sectional study of electronic health records. BMJ 2013, 346:f288.

48. Lundbeck Canada Inc: Celexa (citalopram) Product Monograph. Montreal, QC: Lundbeck Canada Inc; 2012.

49. Lundbeck Canada Inc: Cipralex (escitalopram) Product Monograph. Montreal, QC: Lundbeck Canada Inc; 2012.

50. DeMaio W, Kane CP, Nichols Al, Jordan R: Metabolism studies of desvenlafaxine. J Bioequiv Availab 2011, 3:151-160.

51. Hosoda S, Takimura H, Shibayama M, Kanamura H, Ikeda K, Kumada H: Psychiatric symptoms related to interferon therapy for chronic hepatitis C: clinical features and prognosis. Psychiatry Clin Neurosci 2000, 54:565-572.

52. Scalori A, Pozzi M, Bellia V, Apale P, Santamaria G, Bordoni T, Redaelli A, Avolio A, Parravicini P, Pioltelli $P$, et al: Interferon-induced depression: prevalence and management. Dig Liver Dis 2005, 37(2):102-107.

53. Huet PM, Villeneuve JP: Determinants of drug disposition in patients with cirrhosis. Hepatology 1983, 3(6):913-918.

54. Kasserra C, Hughes E, Treitel M, Gupta S, O'Mara E: Clinical pharmacology of boceprevir: metabolism, excretion, and drug-drug interactions [abstract 118]. In 18th Conference on Retroviruses and Opportunistic Infections. Boston, USA; 2011.

55. Garg V, Chandorkar G, Farmer HF, Smith F, Alves K, Van Heeswijk RPG: Effect of telaprevir on the pharmacokinetics of midazolam and digoxin. J Clin Pharmacol 2012, 52(10):1566-1573.

56. Luo X, Van Heeswijk RPG, Alves K, Garg V: The effect of telaprevir on the pharmacokinetics of alprazolam and zolpidem in healthy volunteers [abstract PK_11]. Rev Antiviral Ther Infect Dis 2011, 6:13.

57. Rifai MA: Hepatitis $C$ treatment of patients with bipolar disorder: a case series. Prim Care Companion J Clin Psychiatry 2006, 8(6):361-366.

58. Powell-Jackson PR, Tredger JM, Williams R: Hepatotoxicity to sodium valproate: a review. Gut 1984, 25(6):673-681.

59. Felker BL, Sloan KL, Dominitz JA, Barnes RF: The safety of valproic acid use for patients with hepatitis C infection. Am J Psychiatry 2003, 160(1):174-178.

60. Argikar UA, Remmel RP: Variation in glucuronidation of lamotrigine in human liver microsomes. Xenobiotica; the fate of foreign compounds in biological systems 2009, 39(5):355-363.

61. Schaffer A, Mclntosh D, Goldstein BI, Rector NA, Mclntyre RS, Beaulieu S, Swinson R, Yatham LN: The CANMAT task force recommendations for the management of patients with mood disorders and comorbid anxiety disorders. Ann Clin Psychiatry 2012, 24(1):6-22.

62. Novartis Pharmaceuticals Canada Inc: Tegretol (Carbamazepine) Product Monograph. Dorval, Que: Novartis Pharmaceuticals Canada Inc; 2011.

63. Andreasen $\mathrm{AH}$, Brosen $\mathrm{K}$, Damkier P: A comparative pharmacokinetic study in healthy volunteers of the effect of carbamazepine and oxcarbazepine on cyp3a4. Epilepsia 2007, 48(3):490-496.

64. Hachad H, Ragueneau-Majlessi I, Levy RH: New antiepileptic drugs: review on drug interactions. Ther Drug Monit 2002, 24(1):91-103.

65. Freudenreich O, Gandhi RT, Walsh JP, Henderson DC, Goff DC: Hepatitis C in schizophrenia: screening experience in a community-dwelling clozapine cohort. Psychosomatics 2007, 48(5):405-411.

66. Sockalingam S, Shammi C, Powell V, Barker L, Remington G: Determining rates of hepatitis $C$ in a clozapine treated cohort. Schizophr Res 2010, 124(1-3):86-90.

67. Matthews AM, Huckans MS, Blackwell AD, Hauser P: Hepatitis C testing and infection rates in bipolar patients with and without comorbid substance use disorders. Bipolar Disord 2008, 10(2):266-270.

68. Telio D, Sockalingam S, Stergiopoulos V: Persistent psychosis after treatment with interferon alfa: a case report. J Clin Psychopharmocol 2006, 26(4):446-447 
69. Thome J, Knopf U: Acute psychosis after injection of pegylated interferon alpha-2a. Eur Psychiatry 2003, 18:142-143.

70. Garcia-Pares G, Domenech C, Gil M: Psychosis induced by interferon-alpha . Psychosomatics 2002, 43:428-429.

71. Hoffman RG, Cohen MA, Alfonso CA, Weiss JJ, Jones S, Keller M, Condermarin JR, Chiu NM, Jacobson JM: Treatment of interferon-induced psychosis in patients with comorbid hepatitis C and HIV. Psychosomatics 2003, 44:417-420.

72. Schafer M, Boetsch T, Laakmann G: Psychosis in a methadone-substituted patient during interferon-alpha treatment of hepatitis C. Addiction 2000, 95(7):1101-1104

73. Constant A, Castera L, Dantzer R, Couzigou P, de Ledinghen V, DemotesMainard J, Henry C: Mood alterations during interferon-alfa therapy in patients with chronic hepatitis C: evidence for an overlap between manic/hypomanic and depressive symptoms. J Clin Psychiatry 2005, 66(8):1050-1057.

74. Onyike CU, Bonner JO, Lyketsos CG, Treisman GJ: Mania during treatment of chronic hepatitis $C$ with pegylated interferon and ribavirin. $\mathrm{Am} J$ Psychiatry 2004, 161(3):429-435.

75. Harrigan EP, Miceli JJ, Anziano R, Watsky E, Reeves KR, Cutler NR, Sramek J, Shiovitz T, Middle M: A randomized evaluation of the effects of six antipsychotic agents on QTc, in the absence and presence of metabolic inhibition. J Clin Psychopharmacol 2004, 24(1):62-69.

76. Merck Canada Inc. MC: Saphris (asenapine) Product Monograph. Kirkland, QC: Merck Canada Inc; 2013.

77. Eiermann B, Engel G, Johansson I, Zanger UM, Bertilsson L: The involvement of CYP1A2 and CYP3A4 in the metabolism of clozapine. Br J Clin Pharmacol 1997, 44(5):439-446.

78. Spina $\mathrm{E}$, de Leon J: Metabolic drug interactions with newer antipsychotics: a comparative review. Basic Clin Pharmacol Toxicol 2007, 100(1):4-22.

79. English BA, Dortch M, Ereshefsky L, Jhee S: Clinically Significant Psychotropic Drug-Drug Interactions in the Primary Care Setting. Curr Psychiatry Rep 2012, 14(4):376-390.

80. AstraZeneca Canada Inc: Seroquel (quetiapine) Product Monograph. Mississauga, ON: AstraZeneca Canada Inc; 2013. April 16.

81. Rajkumar AP, Poonkuzhali B, Kuruvilla A, Jacob M, Jacob KS: Clinical predictors of serum clozapine levels in patients with treatment-resistant schizophrenia. Int Clin Psychopharmacol 2013, 28(1):50-56.

82. Liukkonen T, Sorjonen M, Jokelainen J, Timonen M: Treatment of hepatitis $\mathrm{C}$ with interferon-alpha and ribavirine in a patient with long-term clozapine treatment. Psychosomatics 2008, 49(1):86-88.

83. Boulton DW, DeVane CL, Liston HL, Markowitz JS: In vitro P-glycoprotein affinity for atypical and conventional antipsychotics. Life Sci 2002, 71(2):163-169.

84. Sylvestre DL, Clements BJ: Adherence to hepatitis C treatment in recovering heroin users maintained on methadone. Eur J Gastroenterol Hepatol 2007, 19(9):741-747.

85. Grebely J, Knight E, Genoway KA, Viljoen M, Khara M, Elliott D, Gallagher L, Storms M, Raffa JD, DeVlaming S, et al: Optimizing assessment and treatment for hepatitis $C$ virus infection in illicit drug users: a novel model incorporating multidisciplinary care and peer support. Eur I Gastroenterol Hepatol 2010, 22(3):270-277.

86. Luo X, Trevejo J, van Heeswijk RP, Smith F, Garg V: Effect of telaprevir on the pharmacokinetics of buprenorphine in volunteers on stable buprenorphine/naloxone maintenance therapy. Antimicrob Agents Chemother 2012, 56(7):3641-3647.

87. Sockalingam S, Blank D, Al Jarad A, Alosaimi F, Hirschfield G, Abbey SE: A comparison of depression screening instruments in hepatitis $C$ and the impact of depression on somatic symptoms. Psychosomatics 2011, 52(5):433-440.

88. Hulskotte EGJ, Hwa-Ping F, Bruce RD, Webster LR, Xuan F, O'Mara E, Wagner JA, Butterton JR: Pharmacokinetic interaction between HCV protease inhibitor boceprevir and methadone or buprenorphine in subjects on stable maintenance therapy [abstract PK_09]. Cambridge, MA: 7th International Workshop on Clinical Pharmacology of Hepatitis Therapy; 2012. Rev Antiviral Ther Infect Dis 2012; 6:12.

89. Dbouk B, Arguedas MR, Sheikh A: Assessment of the PHQ-9 as a screening tool for depression in patients with chronic hepatitis C. Dig Dis Sci 2008, 53:1100-1106
90. Knott A, Dieperink E, Willenbring ML, Heit S, Durfee JM, Wingert M, Johnson $J R$, Thuras $\mathrm{P}, \mathrm{Ho}$ SB: Integrated psychiatric/medical care in a chronic hepatitis $C$ clinic: effect on antiviral treatment evaluation and outcomes. Am J Gastroenterol 2006, 101(10):2254-2262.

91. Huckans M, Mitchell A, Ruimy S, Loftis J, Hauser P: Antiviral therapy completion and response rates among hepatitis $C$ patients with and without schizophrenia. Schizophr Bull 2010, 36(1):165-172.

92. Sockalingam S, Blank D, Banga CA, Mason K, Dodd Z, Powis J: A novel program for treating patients with trimorbidity: hepatitis $C$, severe mental illness, and active substance use. Eur $J$ Gastroenterol Hepatol 2013. in press.

doi:10.1186/1471-230X-13-86

Cite this article as: Sockalingam et al:: Psychiatric treatment considerations with direct acting antivirals in hepatitis C. BMC Gastroenterology 2013 13:86.

\section{Submit your next manuscript to BioMed Central and take full advantage of:}

- Convenient online submission

- Thorough peer review

- No space constraints or color figure charges

- Immediate publication on acceptance

- Inclusion in PubMed, CAS, Scopus and Google Scholar

- Research which is freely available for redistribution 